\title{
Evaluating hospitality employees' various relationships and the effects on organizational commitment
}

\author{
Stephanie Bae \\ School of Hospitality Leadership, East Carolina University, \\ Greenville, North Carolina, USA
}

Employees' various relationships

Received 19 January 2021 Revised 30 May 2021 30 July 2021

Accepted 3 September 2021

\begin{abstract}
Purpose - The purpose of this study is to investigate how various relationships an employee builds within the organization affect their willingness to stay with the company. Specific research objective was to examine impact of social exchange on organizational commitment in the hospitality industry.

Design/methodology/approach - An online survey using Qualtrics' panel database was used to collect data. The target was full-time employees in the hospitality industry. A total of 245 surveys were collected and used for data analysis. The results were analyzed using structural equation modeling.

Findings - Results of hypotheses testing showed that internal service quality and perceived organizational support have positive relationships with organizational commitment.

Originality/value - These findings can help hospitality managers develop programs and interact with employees in order to increase commitment and a sense of belonging with the company.
\end{abstract}

Keywords Organizational commitment, Hospitality, Social exchange

Paper type Research paper

\section{Introduction}

Human resources professionals have studied what employees want, as it is proven to be an important factor when recruiting, hiring and retaining the employees. Studies have shown that regardless of their generations, what employees want from their employer do not change as much. For example, Kaye and Jordan-Evans (1999) conducted a survey of more than 3,000 employees in various positions and industries. They found that employees listed people, contribution, autonomy and recognition as being important to them. When the same question was asked in 2020, the answers were similar: people, autonomy and trust, and recognition and appreciation (Heathfield, 2020a, b).

Studies have recognized the importance of organizational commitment for decades. With the global pandemic, hospitality workers face extra work and worry about their job security; it is the employer's responsibility to assure that their employees are able to cope with changes and try to make them feel a sense of belonging with the company (Greger, 2006; Joshi and Bhaskar, 2020). For decades, numerous studies, focusing on a variety of factors, have been conducted on what affects employees' organizational commitment. For example, Bai et al. (2006) and Yao et al. (2019) studied the effect of the quality of internal service on organizational commitment, indicating that the quality of services employees provide to one

(C) Stephanie Bae. Published in International Hospitality Review. Published by Emerald Publishing Limited. This article is published under the Creative Commons Attribution (CC BY 4.0) licence. Anyone may reproduce, distribute, translate and create derivative works of this article (for both commercial and non-commercial purposes), subject to full attribution to the original publication and authors. The full terms of this licence may be seen at http://creativecommons.org/licences/by/4.0/legalcode

The author would like to thank the anonymous reviewers for their valuable comments and helpful suggestions.

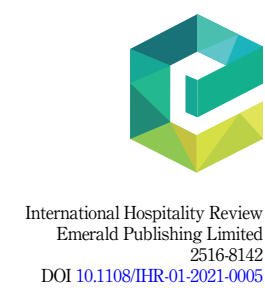


another affects their commitment to the company, whereas Eisenberger et al. (1986) and Wayne et al. (1997) concluded that organizational support is linked to employees' organizational commitment, which indicated that the level of support the employees acquire from their organization influences their organizational commitment. There are other studies claiming that the supervisor-employee relationship is related to organizational commitment (Liden and Maslyn, 1998; Mathieu and Zajac, 1990).

Although there are numerous studies examining different factors influencing organizational commitment of hospitality employees, the majority focused on one or a couple of factors' effects on organizational commitment; despite Meyer and Allen (1997)'s study emphasized that three types of organizational commitment should be viewed as a set, no reported research has been theoretically examined the impact of internal service quality, organizational support and leader-member relationships on organizational commitment using a second-order factor analysis. Therefore, the purpose of this study is to assess whether three antecedents [internal service quality (ISQ), perceived organizational support (POS) and leader-member exchange (LMX)] influence the hospitality employees' organizational commitment. With the COVID pandemic where hospitality employees have experienced and/or witnessed layoffs and furloughs, it is imperative for organizations to understand the various exchange relationships in their company and how they affect the employees' organizational commitment in the COVID-19 pandemic and the post-pandemic.

\section{Literature review}

Social exchange theory

The concept of social exchange (Blau, 1964) has been used to explain how employees develop positive feelings and behaviors toward their organizations. Social Exchange Theory (SET), initially introduced by Blau (1964), indicates that individuals start, maintain or end their exchange relationships based on the perceived ratio of benefits to costs in the relationship (Emerson, 1981; Ensher et al., 2001; Homans, 1974).

Blau (1964) claimed that the exchange relationships can be distinguished between social exchanges and economic exchanges; social exchanges are based on trust that goodwill will be reciprocated in the future, whereas economic exchanges are not. Although Blau (1964) claimed that exchange relationships are causally related, there is no consensus among researchers about the direction of the relationship. However, both Blau (1964) and Cropanzano and Mitchell (2005) agreed that successful exchanges between partners can cause one partner to be committed to the other, indicating that the quality of exchanges can influence the relationship. Cropanzano and Mitchell (2005) concluded that the direction of the causal arrow is a matter of perspective because the relationship may strengthen the exchange or the quality of the exchange can influence the relationship.

One of the most important components of the SET is the norm of reciprocity (Gouldner, 1960). The norm of reciprocity suggests that people feel obligated to repay for what they have received. The reciprocity theory was tested by Kunz and Woolcott (1976) when they sent Christmas cards to a number of strangers. Most of the recipients sent a card back to the researchers, and some even added them to their permanent mailing lists. They concluded that if others have fulfilled our needs, we "repay" them because we feel obligated to do so. In addition, we understand that we should not do harm to those who help us; therefore, we are morally constrained to express gratitude toward them.

As mentioned earlier, SET has been applied when studying workplace relationships. For example, SET has been used to explain the relationship between an organization or its representatives and employees. Employees may form exchange relationships with different members, such as coworkers, supervisors and the organization itself (Dansereau et al., 1975; He et al., 2011; Kim and Qu, 2020; Ladd and Henry, 2000; Loi et al., 2014). When employees are 
treated in a positive and beneficial way by different members within the organization, the employees will feel obligated to maintain a long-term relationship with the members that involves the exchange of socio-emotional benefits (Gouldner, 1960; Lew, 2009; Loi et al., 2014; Ma and Qu, 2011; Settoon et al., 1996; Wayne et al., 2002). However, Wayne et al. (1997) argued that it is not clear when this return will occur and in what form.

\section{Internal service quality}

Internal service quality (ISQ) refers to the service the employee provides to or receives from his/her coworkers (Hallowell et al., 1996; Xie, 2005). ISQ has been used interchangeably with internal marketing; however, the concept of internal service is different from internal marketing. Internal marketing focuses on how well the organization services its employees, whereas internal service focuses more on how well employees serve other employees (Berry, 1981; Frye et al., 2020; George, 1990, To et al., 2015). Internal marketing is more similar to the concept of organizational support than to internal service quality. Some studies claim the support from the employee's coworkers is much more than just work-related; emotional support, such as providing care, love and empathy, is considered to be part of the coworker support (Bani-Melhem et al., 2018; Loi et al., 2014; Rousseau et al., 2009). Since employees and departments are customers of each other, employees are both users and providers of services within the organization, and every employee participates in the exchange relationship (Boshoff and Mels, 1995; McDermott and Emerson, 1991).

In the hospitality industry, there are considerable number of employees in a company who only provide their services to their internal customers (i.e. coworkers); therefore, the quality of internal service affects service quality provided to the external customers (Bai et al., 2006; Xie, 2005). Heskett and his colleagues are one of the few research teams that began to recognize and examine the importance of internal service quality and its overall role. They claimed that internal service quality affects employees' satisfaction, which will lead to their retention (Heskett et al., 1994). Considering the fact that there are studies linking employees' satisfaction to organizational commitment, this study hypothesizes that the quality of internal service affects the employees' organizational commitment:

H1. Employees' perception of internal service quality will be positively related to organizational commitment.

\section{Perceived organizational support}

Perceived organizational support (POS) has been receiving a great deal of attention because POS has proven to increase organizational and individual outcomes (Rhoades and Eisenberger, 2002). POS refers to an employee's perception of the extent to which the organization is concerned about the employee's well-being and values his or her contribution to the organization (Eisenberger et al., 1986). Employees form an idea about whether the organization is willing to compensate them fairly for their efforts, to make their tasks interesting and challenging and to provide them with safe working conditions (Aube et al., 2007). There have been questions about the conceptual distinctiveness between POS and organizational commitment even though they have been proven to be statistically different (Cropanzano and Mitchell, 2005; Shore and Tetrick, 1991; Shore and Wayne, 1993; Wayne et al., 1997). They are conceptually similar; however, POS discusses the organization's commitment to its employees, whereas organizational commitment refers to the employee's commitment to his or her company (Eisenberger et al., 1986; Shore and Shore, 1995).

As mentioned earlier, the concept of Blau (1964)'s social exchange is based on the trust that goodwill will be reciprocated in the future; employees may feel the support they receive from their employer as the organization's commitment to them, which in turn might increase their
Employees' various relationships

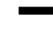


commitment to the company. When employees receive high levels of POS, they may feel obligated to reciprocate the support to the organization. In addition, POS is also associated with the employees' trust that the organization will fulfill the exchange obligations, which is suggested by the norm of reciprocity Therefore, this study hypothesizes that the quality of organizational support affects the employees' organizational commitment:

H2. Employees' perception of organizational support will be positively related to organizational commitment.

\section{Leader-member exchange}

In the past, traditional leadership models failed to examine the effect of leader and employee relationships on employees' behaviors and attitudes (Dansereau et al., 1975; Lee, 2000). Those models were based on the assumptions that employees who report to the same leader have homogeneous perceptions, interpretations and reactions as a work group and that the leader behaves in the same manner toward all of his/her employees (Dansereau et al., 1975; Dunegan et al., 1992). Dansereau et al. (1975) introduced the concept of LMX because they disagreed with the traditional leadership theories mentioned earlier; they believed that a leader develops different and unique exchange relationships with each member of the same group. LMX, therefore, is defined as the exchange relationships a leader develops with each member of the group (Dansereau et al., 1975; Graen and Cashman, 1975; Lee, 2000). The relationship between supervisors and subordinates is based on the concept of social exchange, wherein "each party must offer something the other party sees as valuable and each party must see the exchange as reasonably equitable or fair" (Graen and Scandura, 1987, p. 182). Similar to ISQ, the exchange is both work-related (i.e. material resources and information) and socio-emotional support.

LMX has been divided into two different categories based on the members' roles and the quality of the exchange relationship. The group that develops a better exchange relationship with the leader is called the high-quality LMX group and the group that develops relationships based on the employment contract is called the low-quality LMX group (Graen and Uhl-Bien, 1995). High-quality LMX relationships can be explained in terms of social exchanges as "social exchange tends to engender feelings of personal obligation, gratitude, and trust" (Blau, 1964, p. 94), whereas low-quality LMX relationships have been characterized in terms of economic exchange (Lee, 2000; Liden and Graen, 1980). Based on the literature, it is hypothesized that the quality of a relationships between a leader and a member influences an employee's organizational commitment:

H3. Employees' perception of their supervisor's support will be positively related to organizational commitment.

\section{Organizational commitment}

Organizational commitment has been studied and measured in various ways for decades; there have been numerous antecedents and constructs of organizational commitment identified over the years; yet it is one of the areas that is continuously being studied (Allen and Meyer, 1990; Bai et al., 2006; Caruana and Calleya, 1998; Lew, 2009; Mathieu and Zajac, 1990; Mowday, 1998; Mowday et al., 1979). Organizational commitment is defined as "a psychological link characterized by an attachment due to the employee's needs, wants, and/or obligations that makes it less likely for the employee to leave the organization" (Allen and Meyer, 1996, p. 252). Porter et al. (1974) found that organizational commitment generally has three characteristics: (1) the individual's belief in the goals and values of their organization; (2) the employee's willingness to put a significant amount of effort into the organization; and (3) the employee's desire to maintain membership in the organization.

Several researchers have reported that organizational commitment is a multidimensional construct. Among the studies using more than one construct explaining organizational 
commitment, Meyer and Allen's conceptualization is widely accepted (Allen and Meyer, 1990; Meyer and Allen, 1984, 1991). Meyer and Allen (1984) first proposed two dimensions of organizational commitment: Affective commitment and continuance commitment. Later, Meyer and Allen (1991) finalized their multidimensional commitment model by adding normative commitment as the third construct. Employees with affective commitment stay with the organization because they want to; those with continuance commitment stay because they need to; and individuals with normative commitment remain because they feel they should (Allen and Meyer, 1990).

Allen and Meyer (1990) asserted that the three dimensions are distinguishable components of organizational commitment, not separate types of commitment, so employees may experience each dimension to a different degree. For example, an individual may feel a strong need and obligation to stay with the organization; however, he or she may not have the desire to stay. An employee may feel a strong emotional attachment to the company, but he or she may not need to stay. Therefore, Allen and Meyer (1990) concluded that the total of an employee's commitment reflects each component of organizational commitment. Additionally, Meyer and Allen (1997) claimed that three dimensions of organizational commitment should be considered together as a set instead of specific "different" types of organizational commitment.

In this study it is proposed that ISQ, POS and LMX can enhance organizational commitment of hospitality employees (see Figure 1). According to SET, hospitality employees with high ISQ, POS and LMX would perceive that they maintain exchange relationships with their coworkers, supervisors and the organization as a whole. Based on norm of reciprocity, one of the most important components of SET, the employees feel obligated to return the favor by staying with the organization. As mentioned earlier, Meyer and Allen (1997) asserted that three types of organizational commitment should be considered as a set. Therefore, this study employed second-order factor analysis as it provides a broader picture of a theoretical concept which may not be revealed by first-order factor analysis (Gorsuch, 1983; Kim and Yoon, 2003). This research applied first-order factors (affective commitment, continuance commitment and normative commitment) and a secondorder factor (organizational commitment) to provide different perspectives on theoretical constructs (McClain, 1996).

\section{Methodology}

Measures

The questionnaire was developed based on previously identified measurements, and it consisted of five parts. Part one measured internal service quality. It is consisted of three
Employees' various relationships

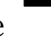


questions from Xie (2005) who revised INTQUAL to measure the quality of internal service. Xie's measures were adapted by researchers in various disciplines (Patah et al., 2009; Skarpeta et al., 2020). For the second part, three items of the SPOS from Settoon et al. (1996), which is a shorter version of the scale developed by Eisenberger et al. (1986), were used to measure employees' perceptions about organizational support. The SPOS has been widely adapted by researchers in multiple industries (e.g. Frey et al., 2017; Huy and Pham, 2021). Part three included questions about LMX; similar to POS, LMX has been examined in numerous industries for decades (e.g. Dulebohn et al., 2012; He et al., 2021). Three items from LMX by Liden and Maslyn (1998) were used. Part four included questions measuring organizational commitment. Allen and Meyer's (1990) Affective Commitment Scale (ACS), Continuance Commitment Scale (CCS) and Normative Commitment Scale (NCS) were used to measure the set of organizational commitment. As they are the most well-known and widely used scales for measuring commitment, these scales were applied and validated for over 30 years (e.g. Luz et al., 2018; Sharma et al., 2020).

The survey questions in part one through four were modified to fit the context of the hospitality industry. Finally, part five included questions about socio-demographic information of participants, such as age, gender, level of education, tenure and ethnicity. Respondents used seven-point Likert scales, ranging from (1) "strongly disagree" to (7) "strongly agree" to respond on the first four parts of the questionnaire.

\section{Sample and data collection}

The target respondents were full-time hospitality employees in the United States. The sampling frame of the study comprised line-level employees and supervisory/managementlevel employees working in the hospitality industry. To reach the sample, Qualtrics' panel database was used to collect the national data. Qualtrics, which is well-known for its survey platform, also has a panel of more than 100 million participants and allows to recruit a nationally representative sample. Qualtrics indicated that their panel data is consistent and reliable due to more than a decade of data and industry benchmarks; they are $47 \%$ more consistent than standard sampling method (Armstrong et al., 2021; Qualtrics, 2021).

An invitation with a link to the survey was sent to the panel members who were working full-time in the hospitality industry to complete the online survey in return for incentives/cash honorarium. The participants are paid for completing the survey. In order to ensure that qualifying respondents are participating in this study, a screening question was used. The screening question asked the potential respondent whether he or she was working full-time in the hospitality industry; lodging, foodservice, travel, conventions and meetings, attractions and leisure were listed as the areas of the hospitality industry (Ottenbacher et al., 2009). Participants who answered no to this question were led to the end of the survey and thanked for their participation. A total of three attention check questions were built into the survey to ensure that the participants read the instructions and answered each question carefully. After the data collection was completed, all responses were reviewed; data cleaning eliminated responses if it took less than 5 min or major items were missing.

\section{Analysis}

The data were formatted for use with SPSS and the Mplus statistical software programs. Factor analyses were used to test whether the constructs existed and could be distinguished from each other (Gall et al., 2007). A second-order factor analysis was applied to improve the generalizability of the structure. The hypothesized relationships among variables were tested using structural equation modeling (SEM) because SEM deals with multiple relationships simultaneously and tests the relationships comprehensively (Hair et al., 2006). 


\section{Results}

A total of 258 questionnaires were collected. Thirteen responses were deleted due to extreme answers or one or more missing answers, and 245 useable responses were kept for further analysis. This is deemed to be suitable as Hair et al. (2006) suggested 10 times as large as the number of variables in the study. In addition, Stevens (1996)'s suggestion of at least 15 cases per measured variable also supports that the sample size of 245 is adequate.

Table 1 presents the demographic profile of the respondents including gender, age, race, highest level of education completed and annual income. Table 1 also shows level of employment and three different types of tenure information including tenure in the current position, tenure in the current organization and tenure in the hospitality industry.

Of the 245 respondents, there were 143 females and 102 males. Over $49 \%$ of the respondents were between the age of 18 and 30 years old, and the mean age of the respondents was 35 years old. Age of the respondents was asked as an open-ended question and was divided into set categories for reporting. The majority of the respondents were Caucasian $(76 \%)$ and had at least some college education $(85 \%)$.

Over $58 \%$ of the respondents were line-level employees including entry-level employees, back-of-the-house and front-of-the-house employees. Approximately $42 \%$ of the respondents were supervisory/management-level employees working in the hospitality industry. In addition to level of employment, respondents answered questions regarding the length of their employment. Each question asked the respondents to indicate how many months they had been working in their current position, in their current organization and in the hospitality industry. All of these data were also divided into set categories (i.e. 5-year segments) for reporting purposes.

Approximately $68 \%$ of the respondents had worked in their current position for five years or less. Tenure in the current position ranged from a month to 35 years, and the mean length of employment in their current position was approximately 51 months. In terms of tenure in their current organization, the majority of the respondents $(64.5 \%)$ worked approximately five years or less. The mean length of employment in their current organization was

\begin{tabular}{llrr}
\hline Variables & Item & $N$ & $\%$ \\
\hline \multirow{2}{*}{ Gender } & Male & 102 & 41.6 \\
Age & Female & 143 & 58.4 \\
& 20 years old or younger & 24 & 9.8 \\
21-30 years old & 96 & 39.2 \\
31-40 years old & 47 & 19.2 \\
& $41-50$ years old & 28 & 11.4 \\
& $51-60$ years old & 34 & 13.9 \\
& 61-70 years old & 14 & 5.7 \\
& 71 years old and older & 2 & 0.8 \\
Ehite/Caucasian & 186 & 75.9 \\
& African American & 22 & 9.0 \\
& Hispanic & 16 & 6.5 \\
& Asian/Pacific Islander & 11 & 4.5 \\
& Native American & 6 & 2.4 \\
& Other & 4 & 1.6 \\
Level of education & Less than high school & 3 & 13.9 \\
& High school/GED & 34 & 49.0 \\
& Some college & 120 & 8.2 \\
& 2-year college degree & 20 & 23.3 \\
& 4-year college degree & 57 & 4.5
\end{tabular}

Employees' various relationships

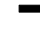


approximately 56 months, and the tenure in their current organization ranged from a month to 27 years. With regard to length of employment in the hospitality industry, $42 \%$ of the respondents had been employed in the hospitality industry for five years or less, while approximately $28 \%$ worked in the hospitality industry between six and 10 years. Tenure in the hospitality industry ranged from a month to 50 years, and the mean length of employment in the hospitality industry was approximately 107 months (see Table 2).

The reliability was tested by Cronbach's alphas to check internal consistency and to ensure that all of the values were at an acceptable level of 0.6 or higher (Tabachnick and Fidell, 1996). The alpha levels ranged from 0.84 to 0.95 ; the level of internal consistency was acceptable. To check for the existence of common method bias among the constructs, Harman's single factor test was performed. The results of the test indicated that $44.2 \%$ of the variance was explained by one general factor; this is less than the suggested cutoff of $50 \%$ which suggests that common method bias does not pose a threat in interpreting the results (Podsakoff et al., 2003).

Factor analysis was performed to evaluate the adequacy of the overall fit of measurement items in the conceptual model. As mentioned earlier, a second-order factor analysis was used to understand the facets of organizational commitment. Figure 2 presents the results of the second-order model for organizational commitment. The initial estimation of the measurement model was found to have an acceptable fit: $\chi^{2}=268.14$ [df $\left.=120, p<0.001\right]$, $\mathrm{CFI}=0.958$, TLI $=0.947$, RMSEA $=0.077$ and SRMR $=0.045$. The average variance extracted (AVE) was calculated to assess convergent and discriminant validity, and all AVE values were higher than 0.5 which confirmed convergent validity. To assess discriminant validity, squared correlation coefficients were compared to AVE values. All AVE values were greater than squared correlation coefficient which showed discriminant validity (Fornell and Larcker, 1981) (see Table 3).

After confirming the model fit, the relationships among the variables in the model were examined via SEM. The structural model proposed the causal relationships between ISQ, POS and LMX and organizational commitment. Organizational commitment had been used as a second-order factor of three first-order factors (affective commitment, continuance commitment, and normative commitment). The full measurement model consisted of six

\begin{tabular}{|c|c|c|c|}
\hline Variables & Item & $N$ & $\%$ \\
\hline \multirow[t]{2}{*}{ Level of employment } & Management/Supervisory & 101 & 41.2 \\
\hline & Line-level & 144 & 58.8 \\
\hline \multirow[t]{5}{*}{ Tenure in the current position } & 5 years or less & 168 & 68.6 \\
\hline & $6-10$ years & 48 & 19.6 \\
\hline & $11-15$ years & 17 & 6.9 \\
\hline & $16-20$ years & 9 & 3.7 \\
\hline & 21 years and more & 3 & 1.2 \\
\hline \multirow[t]{5}{*}{ Tenure in the current organization } & 5 years or less & 158 & 64.5 \\
\hline & $6-10$ years & 53 & 21.6 \\
\hline & $11-15$ years & 22 & 9.0 \\
\hline & $16-20$ years & 6 & 2.4 \\
\hline & 21 years and more & 6 & 2.4 \\
\hline \multirow[t]{6}{*}{ Tenure in the hospitality industry } & 5 years or less & 103 & 42.0 \\
\hline & $6-10$ years & 68 & 27.8 \\
\hline & $11-15$ years & 22 & 9.0 \\
\hline & $16-20$ years & 18 & 7.3 \\
\hline & $21-25$ years & 13 & 5.3 \\
\hline & 26 years and more & 21 & 8.6 \\
\hline
\end{tabular}

Table 2.

Employment

information $(N=245)$ 


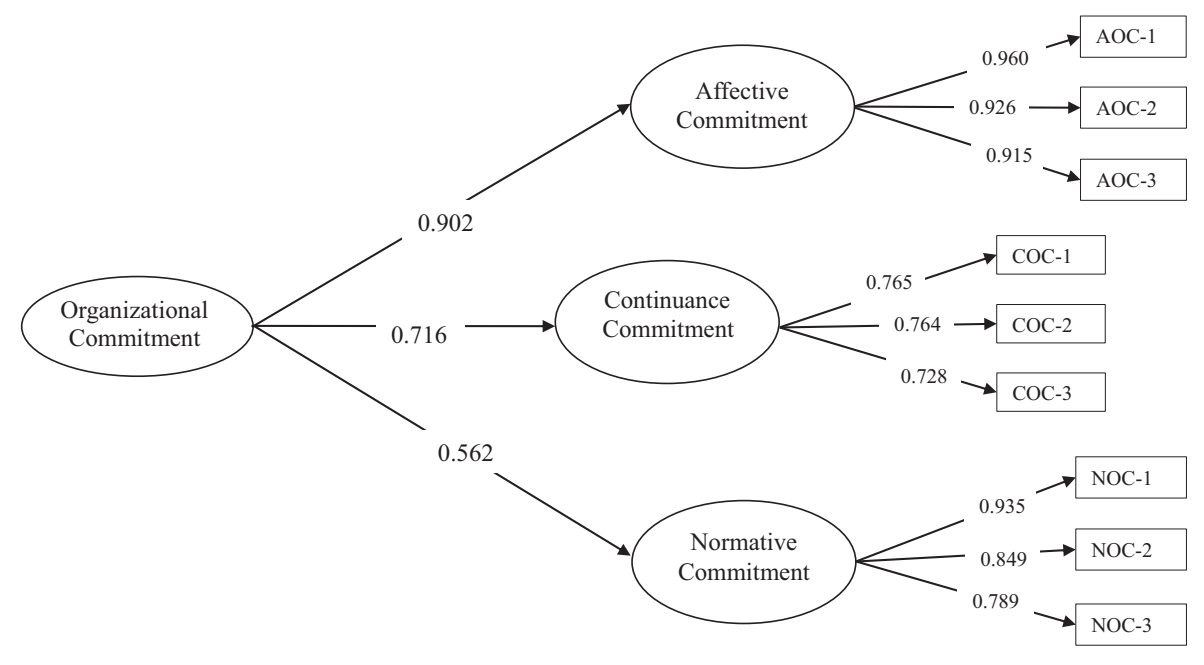

\section{Employees' various relationships}

\begin{tabular}{lllllll}
\hline Construct & ISQ & POS & LMX & AOC & COC & NOC \\
\hline
\end{tabular}

Internal service quality (ISQ)

Perceived organizational support (POS)

Leader-member exchange (LMX)

Affective commitment (AOC)

Continuance commitment (COC)

Normative commitment (NOC)

Cronbach's alpha

Average variance extracted
1

$0.45 \quad 1$

$0.39 \quad 0.62$

$0.42 \quad 0.59$

$0.32 \quad 0.27$

$0.32 \quad 0.43$

$0.84 \quad 0.94$

$0.85 \quad 0.92$

1
0.69
0.20
0.57
0.92
0.81

1 0.33

0.61

0.95

0.95
1

0.26

0.85

0.80
1

0.88

0.89
Table 3.

Correlation coefficients, reliability and AVE of constructs
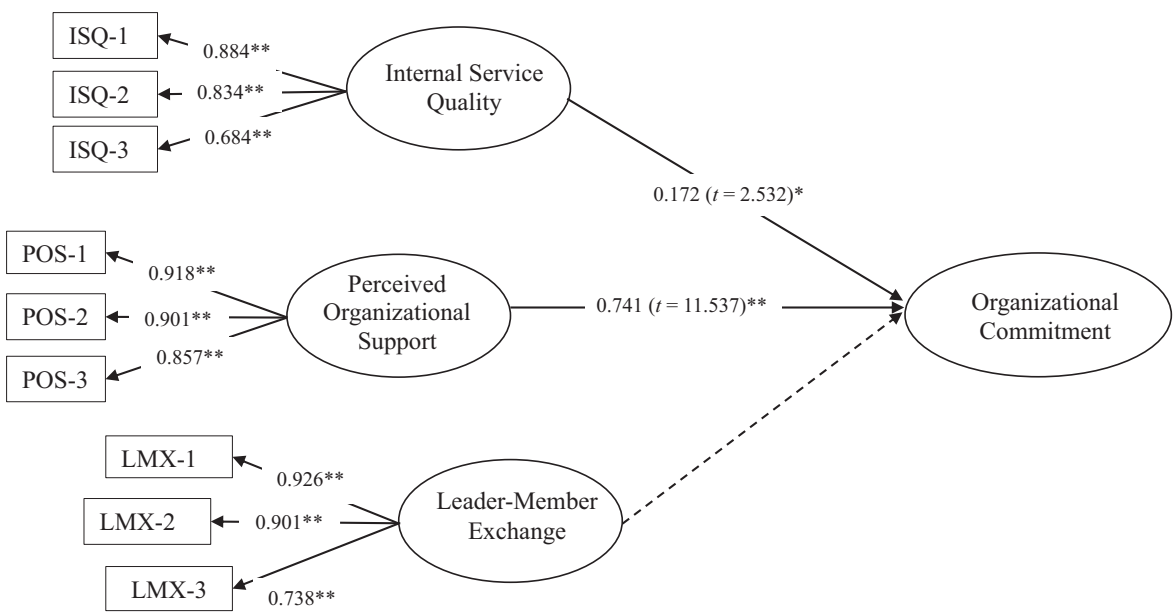

Note(s): $\chi^{2}(126)=310.660, p<0.001, \mathrm{CFI}=0.948, \mathrm{TLI}=0.937, \mathrm{RMSEA}=0.077$, and $\mathrm{SRMR}=0.060$. $* p<0.05, * * p<0.01$

Figure 3.

SEM results of the research model 
constructs and 18 measurement items. The results indicated an excellent model fit: $\chi^{2}=310.660$ [df $\left.=126, p<0.001\right]$, CFI $=0.948$, TLI $=0.937$, RMSEA $=0.077$ and $\mathrm{SRMR}=0.060$; the chi-square to degrees of freedom ratio was 2.47 , which is considered to be a good fit since it should be between one and three (McIver and Carmines, 1981). As shown in Figure 2, an examination of path estimates indicated that ISQ and POS had significant positive direct effects on the organizational commitment $\beta=0.172, p<0.05$ and $\beta=0.741$, $p<0.01$ respectively), supporting $\mathrm{H} 1$ and H2. Only one construct, LMX, did not show a significant direct effect on organizational commitment $(\beta=0.062, p>0.05)$; therefore, $\mathrm{H} 3$ was not supported.

\section{Discussion and conclusions}

The purpose of this study was to investigate how various relationships an employee builds within the organization affect their willingness to stay with a company. Based on SET, a theoretical model was developed to test the relationships between ISQ, POS and LMX and the three dimensions of organizational commitment by using a second-order factor analysis. Results of this study revealed that internal service quality positively influenced organizational commitment. This is consistent with previous studies in the non-hospitality industry both in the United States and other countries (Bai et al., 2006; Hallowell et al., 1996; Li et al., 2019; Shinnar, 1998; Xie, 2005). Hospitality employees who feel that their coworkers provide both work-related and emotional support showed a stronger commitment to their company. Even though the COVID-19 pandemic minimized some exchange relationships in the workplace, the quality of the service they receive from their coworkers matters.

This research study also found that POS positively affects organizational commitment. This confirms the findings of previous studies (Aube et al., 2007; Cheng and Yi, 2018; Eisenberger et al., 1986; Shore and Shore, 1995; Wayne et al., 1997). When employees feel that their organization cares about their opinions or well-being, they feel that they ought to be committed because employees feel that the organization is committed to them (Cheng and $\mathrm{Yi}$, 2018; Eisenberger et al., 1986; Shore and Shore, 1995). The strong relationship between POS and organizational commitment may be attributed to the COVID pandemic where hospitality employees have experienced frequent layoffs and furloughs. In times like these, they view that an organization cares about their employees more significant compared to the time before the pandemic.

LMX did not show any significant relationship with organizational commitment. This is not a surprise as some hospitality employees might not have much direct contact with their supervisor. Many positions, such as bell staff, may work autonomously and have more contact with their coworkers than with their supervisor. In addition, the employees might not be working closely with their supervisors due to the extenuating circumstances, such as the current pandemic. Just like workers in many other industries, hospitality employees, especially in sales or revenue departments, work remotely at home collaborating with their colleagues on their projects. This could explain why LMX was not a significant predictor of the organizational commitment in the hospitality industry.

In addition to the predictors, this study also claims that organizational commitment should be viewed as a set in the hospitality industry. As mentioned earlier, Meyer and Allen (1997), who first proposed and tested various dimensions of organizational commitment, claimed that organizational commitment has three dimensions. They asserted that it should be considered together, as a set, instead of different types of organizational since they are often all felt at the same time to varying degrees.

\section{Practical implications}

This study has practical implications; the findings from this study can provide employee commitment and retention strategies for management in the hospitality industry. First, the 
quality of services that employees receive from their coworkers has a significant relationship to their organizational commitment. While some employees work very closely with their supervisors, cooks and chefs for example, many hospitality employees may not. Employees tend to work much more closely with their coworkers in the hospitality industry. Thus, organizations should focus on the quality of exchange relationships among coworkers by developing a culture of cooperation in the organization. Even though a lot of activities that could be done may not be possible due to the COVID-19 pandemic, where in-person contacts are being discouraged to prevent the spread of the virus, companies could host virtual events where employees can interact and build exchange relationships with their coworkers safely. Previous studies have shown that a good corporate culture motivates employees to stay with the organization (Gephart et al., 1996). Therefore, organizations should build a culture of organizational support that emphasizes internal customer service. For example, organizations can emphasize the importance of internal services during orientation, training and pre-shift meetings. They can also help build relationships through corporate outings such as picnics, family events, holiday parties or by hosting lunch together once a month of a quarter which might help improve employee morale. Furthermore, POS was found to have an impact on organizational commitment. Thus, employees, who perceive that their organization cares about them and is committed to them, will repay the organization with higher levels of commitment. In addition, higher perceived organizational support creates a sense of obligation to reciprocate the organization's commitment by supporting its goals and objectives (Tremblay et al., 2019; Wayne et al., 1997). Hospitality organizations should show their commitment to their employees in order to increase employees' organizational commitment. Increasing the support the organization exhibits to employees or showing employees that the organization cares about their well-being will positively influence employee commitment. Organizations can introduce employee recognition programs (e.g. Employee of the Month) or work-life balance initiatives (i.e. providing daycare, work from home days) to show their employees that they are valued members of the organization.

Due to COVID-19, various hospitality organizations have been forced to furlough their employees. When companies go through this process with employees, they should take time to explain to their employees how much the company values them, how hard of a decision this is and that they will bring them back when they are in a position to bring them again. While some of these suggestions will cost an organization money, there are other initiatives that managers can take to increase employee commitment that are free.

\section{Theoretical implications}

One of the major theoretical implications from this study is the development of an employee relationships model using SET. To the author's knowledge, there is no model examining the quality of employees' relationships with their coworkers, their company and their supervisor and the effect they have on organizational commitment. In addition, this study has also employed a second-order factor analysis for organizational commitment to provide a broader picture of SET; previous studies focusing on organizational commitment investigated either general organizational commitment or one or two types of organizational commitment. However, this study's results contribute to the extant literature by enhancing the current knowledge regarding the use of a set of three types of organizational commitment in the exchange relationships study focusing on the hospitality employees.

\section{Limitations and future research}

As with most research, there are several limitations associated with this study. First, limitations arise from the sample used. This research was available to employees who are part of the panel. The results may have been different if the questionnaire was available to a
Employees' various relationships 
different sample of hospitality employees. Future study may examine this model with more generalizable sample and test to see if they can replicate the study. In addition, this study collected data regardless of the level of employment (i.e. supervisory or line-level) and the segment in which they worked. Both an employee working in a fine-dining restaurant and an employee working in a fast-food restaurant could participate in this study; both an assistant manager and a line-level could also participate in the research. Working conditions and the factors related to these jobs are distinctively different. Future research may examine employees by segment and compare the differences between segments and also test the possible difference between supervisory-level employees and line-level employees.

Second, this study specifically focused on the effects of ISQ, POS and LMX on organizational commitment. There are numerous antecedents of organizational commitment; however, this study limited the scope to three factors. If this study examined other antecedents such as job satisfaction, distributive justice or benefit satisfaction, the results may have been different. Future research should test additional factors based on the literature to test the model. Additionally, future research should also consider building models to test if there are any possible mediators and/or moderators of these relationships. For instance, Robson and Robson (2016) studied nurses' intention to leave, which is closely linked to organizational commitment and found that POS and LMX play a significant role in leave intention that is partially mediated by affective commitment. Casimir et al. (2014) found that affective commitment mediates the relationships between LMX and in-role performance and POS and in-role performance. Although this research built and focused on the model (see Figure 1), future research should further investigate other possibilities of social exchange relationships.

Last, the design of the study is cross-sectional, where the data were collected from the respondents at a single point in time. Unlike personality traits, which are relatively stable over time, attitudes are susceptible to change. Therefore, the causal relationships between variables are prone to biases (Bobko and Stone-Romero, 1998, as cited in Lee, 2012). Future research can use a longitudinal design to validate causal relationships. As mentioned earlier, this study collected the data from respondents at one point in time. Thus, an employee who is unhappy with his or her job may have reported positively on the survey if, for example, that employee just received a large commission check. On the contrary, an employee who has been happy with his or her job might report negatively on the survey if that employee was under the pressure of a deadline. Future research can employ a longitudinal method to examine the continuity of the responses and to observe any changes that may occur over a period of time (Zikmund et al., 2012).

\section{References}

Allen, N.J. and Meyer, J.P. (1990), "The measurement and antecedents of affective, continuance, and normative commitment to the organization”, Journal of Occupational Psychology, Vol. 63, pp. 1-18.

Allen, N.J. and Meyer, J.P. (1996), "Affective, continuance, and normative commitment to the organization: an examination of construct validity", Journal of Vocational Behavior, Vol. 49, pp. 252-276.

Armstrong, B., Reynolds, C., Bridge, G., Oakden, L., Wang, C., Panzone, L., Schmidt Rivera, X., Kause, A., Foulkes, C., Krawczyk, C., Miller, G. and Serjeant, S. (2021), "How does citizen science compare to online survey panels? A comparison of food knowledge and perceptions between the Zooniverse, Prolific and Qualtrics UK Panels", Frontiers in Sustainable Food Systems, Vol. 4, pp. 1-11.

Aube, C., Rousseau, V. and Morin, E.M. (2007), "Perceived organizational support and organizational commitment: the moderating effect of locus of control and work autonomy", Journal of Managerial Psychology, Vol. 22 No. 5, pp. 479-495. 
Bai, B., Brewer, K.P., Sammons, G.E. and Swerdlow, S. (2006), "Job satisfaction, organizational commitment, and internal service quality: a case study of Las Vegas hotel/casino industry", Journal of Human Resources in Hospitality and Tourism, Vol. 5 No. 2, pp. 37-54.

Bani-Melhem, S., Zeffane, R. and Albaity, M. (2018), "Determinants of employees' innovative behavior", International Journal of Contemporary Hospitality Management, Vol. 30 No. 3, pp. 1601-1620.

Berry, L.L. (1981), "The employee as customer”, Journal of Retail Banking, Vol. 3 No. 1, pp. 33-40.

Blau, P.M. (1964), Exchange and Power in Social Life, John Wiley \& Sons, New York, NY.

Bobko, P. and Stone-Romero, E.F. (1998), "Meta-analysis may be another useful research tool, but it is not a panacea", in Ferris, G.R. (Ed.), Research in Personnel and Human Resources Management, JAI Press Stamford, CT, pp. 359-397.

Boshoff, C. and Mels, G. (1995), "A causal model to evaluate the relationships among supervision, role stress, organizational commitment and internal service quality", European Journal of Marketing, Vol. 29 No. 2, pp. 23-42.

Caruana, A. and Calleya, P. (1998), "The effect of internal marketing on organizational commitment among retail bank managers", International Journal of Bank Marketing, Vol. 16 No. 3, pp. 108-116.

Casimir, G., Ng, Y.N.K., Wang, K.Y. and Ooi, G. (2014), "The relationships amongst leader-member exchange, perceived organizational support, affective commitment, and in-role performance: a social-exchange perspective", Leadership and Organization Development Journal, Vol. 35 No. 5, pp. 366-385.

Cheng, J.C. and Yi, O. (2018), "Hotel employee job crafting, burnout, and satisfaction: the moderating role of perceived organizational support", International Journal of Hospitality Management, Vol. 72, pp. 78-85.

Cropanzano, R. and Mitchell, M.S. (2005), "Social exchange theory: an interdisciplinary review", Journal of Management, Vol. 31 No. 6, pp. 874-900.

Dansereau, F., Graen, G. and Haga, W.J. (1975), "A vertical dyad linkage approach to leadership within formal organizations: a longitudinal investigation of the role making process", Organizational Behavior and Human Performance, Vol. 13, pp. 46-78.

Dulebohn, J.H., Bommer, W.H., Liden, R.C., Brouer, R.L. and Ferris, G.R. (2012), “A meta-analysis of antecedents and consequences of leader-member exchange: integrating the past with an eye toward the future", Journal of Management, Vol. 38 No. 6, pp. 1715-1759.

Dunegan, K.J., Duchon, D. and Uhl-Bien, M. (1992), "Examining the link between leader-member exchange and subordinate performance: the role of task analyzability as moderators", Journal of Management, Vol. 18 No. 1, pp. 59-76.

Eisenberger, R., Huntington, R., Hutchison, S. and Sowa, D. (1986), "Perceived organizational support", Journal of Applied Psychology, Vol. 71 No. 3, pp. 500-507.

Emerson, R.M. (1981), "Social exchange theory", in Rosenberg, M. and Turner, R.H. (Eds), Social Psychology: Sociological Perspectives, Basic Books, New York, NY.

Ensher, E.A., Thomas, C. and Murphy, S.E. (2001), "Comparison of traditional, step-ahead, and peer mentoring on proteges' support, satisfaction, and perceptions of career success: a social exchange perspective", Journal of Business and Psychology, Vol. 15 No. 3, pp. 419-438.

Fornell, C. and Larcker, D. (1981), "Structural equation models with unobservable variables and measurement error", Journal of Marketing Research, Vol. 18 No. 1, pp. 39-50.

Frey, L.L., Beesley, D., Abbott, D. and Kendrick, E. (2017), "Vicarious resilience in sexual assault and domestic violence advocates", Psychological Trauma: Theory, Research, Practice, and Policy, Vol. 9 No. 1, pp. 44-51.

Frye, W.D., Kang, S., Huh, C. and Lee, M.J.M. (2020), "What factors influence Generation Y's employee retention in the hospitality industry?: an internal marketing approach", International Journal of Hospitality Management, Vol. 85, pp. 1-9.
Employees' various relationships 
Gall, M.D., Gall, J.P. and Borg, W.R. (2007), Educational Research: an Introduction, 8th ed., Pearson, Boston, MA.

George, W.R. (1990), "Internal marketing and organizational behavior: a partnership in developing customer-conscious employees at every level”, Journal of Business Research, Vol. 20 No. 1, pp. 63-70.

Gephart, M.A., Marsick, V.J., Van Buren, M.E. and Spiro, M.S. (1996), "Learning organizations come alive", Training and Development, Vol. 50 No. 12, pp. 34-45.

Gorsuch, R.L. (1983), Factor Analysis, 2nd ed., Lawrence Erlbaum Associates, Hillsdale, NJ.

Gouldner, A.W. (1960), “The norm of reciprocity: a preliminary statement”, American Sociological Review, Vol. 25 No. 2, pp. 161-178.

Graen, G.B. and Cashman, J. (1975), "A role-making model of leadership in formal organizations: a developmental approach”, in Hunt, J.G. and Lawson, L.L. (Eds), Leadership Frontiers, Kent State University Press, Kent, OH, pp. 143-166.

Graen, G.B. and Scandura, T.A. (1987), "Toward a psychology of dyadic organizing”, Research in Organizational Behavior, Vol. 9, pp. 175-208.

Graen, G.B. and Uhl-Bien, M. (1995), "Relationship-based approach to leadership: development of leader-member exchange (LMX) theory of leadership over 25 years: applying a multi-level multi-domain perspective”, Leadership Quarterly, Vol. 6 No. 2, pp. 219-247.

Greger, K. (2006), "Statistics show worker shortage expected within decade", Hotel and Motel Management, Vol. 221 No. 14, pp. 8-14.

Hair, J.F., Anderson, R.E., Tatham, R.L. and Black, W.C. (2006), Multivariate Data Analysis, 6th ed., Prentice-Hall, Upper Saddle River, NJ.

Hallowell, R., Schlesinger, L.A. and Zornitsky, J. (1996), "Internal service quality, customer and satisfaction: linkages and implications for management", Human Resource Planning, Vol. 19, pp. 20-31.

He, Y., Lai, K.K. and Lu, Y. (2011), "Linking organizational support to employee commitment: evidence from hotel industry of China", The International Journal of Human Resource Management, Vol. 22 No. 1, pp. 197-217.

He, C., McCabe, B. and Jia, G. (2021), "Effect of leader-member exchange on construction worker safety behavior: safety climate and psychological capital as the mediators", Safety Science, Vol. 142, pp. 1-9.

Heathfield, S.M. (2020a), "Top ideas about what employees want from their workplace", The Balance Career, available at: https://www.thebalancecareers.com/top-ideas-about-what-employees-wantfrom-work-1919064.

Heathfield, S.M. (2020b), "Factors ever employee wants from work: business management success tips", The Balance Career, available at: https://www.thebalancecareers.com/what-employeeswant-1918690.

Heskett, J.L., Jones, T.O., Loveman, G.W., Sasser, W.E. Jr and Schlesinger, L.A. (1994), "Putting the service-profit chain to work", Harvard Business Review, Vol. 72 No. 2, pp. 164-170.

Homans, G.C. (1974), Social Behavior: its Elementary Forms, Harcourt Brace Jovanovich, New York, NY.

Huy, P.T. and Pham, H.C. (2021), "Effect of management commitment to service quality on car-hailing drivers' service behaviors: the case of GrabCar in Vietnam", Organizacija, Vol. 54 No. 2, pp. 131-146.

Joshi, A. and Bhaskar, P. (2020), "COVID-19: impact of lockdown on tourism and hospitality industry", Business Excellence and Management, Vol. 10 No. 5, pp. 147-154.

Kaye, B. and Jordan-Evans, S. (1999), Love'em or Lose'em: Getting Good People to Stay, BerrettKoehler, San Francisco, CA. 
Kim, H. and Qu, H. (2020), "The mediating roles of gratitude and obligation to link employees' social exchange relationships and prosocial behavior", International Journal of Contemporary Hospitality Management, Vol. 32 No. 2, pp. 644-664.

Kim, S. and Yoon, Y. (2003), "The hierarchical effects of affective and cognitive components on tourism destination image", Journal of Travel and Tourism Marketing, Vol. 14 No. 2, pp. 1-22.

Kunz, P.R. and Woolcott, M. (1976), "Season's greetings: from my status to yours", Social Science Research, Vol. 5 No. 3, pp. 269-278.

Ladd, D. and Henry, R.A. (2000), "Helping coworkers and helping the organization: the role of support perceptions, exchange ideology, and conscientiousness", Journal of Applied Social Psychology, Vol. 30 No. 10, pp. 2028-2049.

Lee, H. (2000), An Empirical Study of Organizational Justice as a Mediator of the Relationships Among Leader-Member Exchange and Job Satisfaction, Organizational Commitment, and Turnover Intentions in the Lodging Industry, Doctoral dissertation.

Lee, J. (2012), Antecedents and Consequences of Employee Engagement: Empirical Study of Hotel Employees and Managers, Doctoral dissertation.

Lew, T. (2009), "The relationships between perceived organizational support, felt obligation, affective organizational commitment and turnover intention of academics working with private higher educational institutions in Malaysia”, European Journal of Social Sciences, Vol. 9 No. 1, pp. $72-87$.

Li, L., Zhu, B., Cai, X., Long, X. and Park, C. (2019), “Internal service quality affects salespersons' performance and turnover intention: mediating role of job involvement", Social Behavior and Personality: An International Journal, Vol. 47 No. 8, pp. 1-11.

Liden, R.C. and Graen, G. (1980), "Generalizability of the vertical dyad linkage model of leadership", Academy of Management Journal, Vol. 23 No. 3, pp. 451-465.

Liden, R.C. and Maslyn, J.M. (1998), "Multidimensionality of leader-member exchange: an empirical assessment through scale development”, Journal of Management, Vol. 24 No. 1, pp. 43-72.

Loi, R., Ao, O.K.Y. and Xu, A.J. (2014), "Perceived organizational support and coworker support as antecedents of foreign workers' voice and psychological stress", International Journal of Hospitality Management, Vol. 36 No. 1, pp. 23-30.

Luz, C.M.D.R., de Paula, S.L. and de Oliveira, L.M.B. (2018), "Organizational commitment, job satisfaction and their possible influences on intent to turnover", Revista de Gestao, Vol. 25 No. 1, pp. 84-101.

Ma, E. and Qu, H. (2011), "Social exchanges as motivators of hotel employees' organizational citizenship behavior: the proposition and application of a new three-dimensional framework", International Journal of Hospitality Management, Vol. 30 No. 3, pp. 680-688.

Mathieu, J.E. and Zajac, D.M. (1990), "A review and meta-analysis of the antecedents, correlates, and consequences of organizational commitment”, Psychological Bulletin, Vol. 108 No. 2, pp. 171-194.

McClain, A.L. (1996), "Hierarchical analytic methods yielding different perspectives on data dynamics: aids to interpretation", in Thompson, B. (Ed.), Advances in Social Science Methodology, JAT Press, Greenwich, CT, pp. 229-240.

McDermott, L.C. and Emerson, M. (1991), "Quality and service for internal customers”, Training and Development Journal, Vol. 45 No. 1, pp. 61-64.

McIver, J.P. and Carmines, E.G. (1981), Unidimensional Scaling, Sage Publication, Thousand Oaks, CA.

Meyer, J.P. and Allen, N.J. (1984), "Testing the 'side-bet theory' of organizational commitment: some methodological considerations”, Journal of Applied Psychology, Vol. 69 No. 3, pp. 372-378.

Meyer, J.P. and Allen, N.J. (1991), "A three-component conceptualization of organizational commitment”, Human Resource Management Review, Vol. 1 No. 1, pp. 61-89.

Meyer, J.P. and Allen, N.J. (1997), Commitment in the Workplace: Theory, Research, and Application, Sage Publication, Thousand Oaks, CA.
Employees' various relationships 
Mowday, R.T. (1998), "Reflections of the study and relevance of organizational commitment", Human Resource Management Review, Vol. 8 No. 4, pp. 387-401.

Mowday, R.T., Steers, R.M. and Porter, L.W. (1979), "The measurement of organizational commitment", Journal of Vocational Behavior, Vol. 14, pp. 224-247.

Ottenbacher, M., Harrington, R. and Parsa, H.G. (2009), "Defining the hospitality discipline: a discussion of pedagogical and research implications", Journal of Hospitality and Tourism Research, Vol. 33 No. 3, pp. 263-283.

Patah, A., Rashdi, M.O., Zain, R.A., Abdullah, D. and Mohd Radzi, S. (2009), “An empirical investigation into the influences of psychological empowerment and overall job satisfaction on employee loyalty", Journal of Tourism, Hospitality and Culinary Arts, Vol. 1 No. 3, pp. 1-20.

Podsakoff, P.M., MacKenzie, S.B., Lee, J.Y. and Podsakoff, N.P. (2003), "Common method biases in behavioral research: a critical review of the literature and recommended remedies", Journal of Applied Psychology, Vol. 88 No. 5, pp. 879-903.

Porter, L.W., Steers, R.M., Mowday, R.T. and Boulian, P.V. (1974), "Organizational commitment, job satisfaction, and turnover among psychiatric technicians", Journal of Applied Psychology, Vol. 59 No. 5, pp. 603-609.

Qualtrics (2021), "Unlock breakthrough insights with market research panels”, available at: https:// www.qualtrics.com/research-services/online-sample/.

Rhoades, L. and Eisenberger, R. (2002), "Perceived organizational support: a review of Literature", Journal of Applied Psychology, Vol. 87 No. 4, pp. 698-714.

Robson, A. and Robson, F. (2016), "Investigation of nurses' intention to leave: a study of a sample of UK nurses", Journal of Health Organization and Management, Vol. 30 No. 1, pp. 154-173.

Rousseau, V., Salek, S., Aubé, C. and Morin, E.M. (2009), "Distributive justice, procedural justice, and psychological distress: the moderating effect of coworker support and work autonomy", Journal of Occupational Health Psychology, Vol. 14, pp. 305-317.

Settoon, R.P., Bennett, N. and Liden, R.C. (1996), "Social exchange in organizations: perceived organizational support, leader-member exchange, and employee reciprocity", Journal of Applied Psychology, Vol. 81 No. 3, pp. 219-227.

Sharma, K., Licsandru, T.C., Gupta, S., Aggarwal, S. and Kanungo, R. (2020), "An investigation into corporate trust and its linkages", Journal of Business Research, Vol. 117, pp. 806-824.

Shinnar, R. (1998), The Relationship between Employee Benefit Satisfaction and Organizational Commitment, Master's thesis.

Shore, L.M. and Shore, T.H. (1995), "Perceived organizational support and organizational justice", in Cropanzano, R. and Kacmar, K.M. (Eds), Organizational Politics, Justice, and Support: Managing Social Climate at Work, Quorum Press, Westport, CT, pp. 149-164.

Shore, L.M. and Tetrick, L.E. (1991), "A construct validity study of the survey of perceived organizational support”, Journal of Applied Psychology, Vol. 76 No. 5, pp. 637-643.

Shore, L.M. and Wayne, S.J. (1993), "Commitment and employee behavior: comparison of affective commitment and continuance commitment with perceived organizational support", Journal of Applied Psychology, Vol. 78 No. 5, pp. 774-780.

Skarpeta, K., Koemtzi, M. and Aidonis, D. (2020), "Measuring internal service quality: the case of the Greek public higher education institutions", The TQM Journal, Vol. 32 No. 2, pp. 268-287.

Stevens, J. (1996), Applied Multivariate Statistics for the Social Sciences, 3rd ed., Lawrence Erlbaum Associates, Mahwah, NJ.

Tabachnick, B.G. and Fidell, L.S. (1996), Using Multivariate Statistics, 3rd ed., HarperCollins, New York, NY.

To, W.M., Martin, E.F. and Yu, B.T.W. (2015), "Effect of management commitment to internal marketing on employee work attitude", International Journal of Hospitality Management, Vol. 45, pp. 14-21. 
Tremblay, M., Gaudet, M.C. and Vandenberghe, C. (2019), "The role of group-level perceived organizational support and collective affective commitment in the relationship between leaders' directive and supportive behaviors and group-level helping behaviors", Personnel Review, Vol. 48 No. 2, pp. 417-437.

Wayne, S.J., Shore, L.M. and Liden, R.C. (1997), "Perceived organizational support and leader-member exchange: a social exchange perspective", Academy of Management Journal, Vol. 40 No. 1, pp. 82-111.

Wayne, S.J., Shore, L.M., Bommer, W.H. and Tetrick, L.E. (2002), "The role of fair treatment and rewards in perceptions of organizational support and leader-member exchange", Journal of Applied Psychology, Vol. 87 No. 3, pp. 590-598.

Xie, D. (2005), Exploring Organizational Learning Culture, Job Satisfaction, Motivation to Learn, Organizational Commitment, and Internal Service Quality in a Sport Organization, Doctoral dissertation.

Yao, T., Qiu, Q. and Wei, Y. (2019), "Retaining hotel employees as internal customers: effect of organizational commitment on attitudinal and behavioral loyalty of employees", International Journal of Hospitality Management, Vol. 76, pp. 1-8.

Zikmund, W.G., Babin, B.J., Carr, K.C. and Griffin, M. (2012), Business Research Methods, 9th ed., South-Western, Mason, $\mathrm{OH}$.

\section{Corresponding author}

Stephanie Bae can be contacted at: baej17@ecu.edu
Employees' various relationships 